\title{
Tracing organic matter sources of estuarine tidal flat nematodes with stable carbon isotopes
}

\author{
Tom Moens ${ }^{1, *}$, Caroline Luyten ${ }^{1}$, Jack J. Middelburg ${ }^{2}$, Peter M. J. Herman ${ }^{2}$, \\ Magda Vincx ${ }^{1}$
}

\author{
${ }^{1}$ University of Gent, Biology Department, Marine Biology Section, K.L. Ledeganckstraat 35, 9000 Gent, Belgium \\ ${ }^{2}$ Netherlands Institute for Ecology, Centre for Estuarine and Coastal Ecology, Korringaweg 7, PO Box 140, \\ 4400 AC Yerseke, The Netherlands
}

\begin{abstract}
The present study explores the use of stable carbon isotopes to trace organic matter sources of intertidal nematodes in the Schelde estuary (SW Netherlands). Stable carbon isotope signatures of nematodes from a saltmarsh and 4 tidal flat stations were determined in spring and winter situations, and compared to isotope ratios of organic matter sources within the estuary. Nematodes collected from fine sandy tidal flat sediments in late spring and during mild and sunny late winter weather had $\delta^{13} \mathrm{C}$ values consistent with microphytobenthos as their prime carbon source. Nematodes from a silty station and individuals sampled under cold and dark winter conditions had $\delta^{13} \mathrm{C}$ values intermediate between those of microalgae and particulate organic matter. The isotopic signatures of nematodes from the saltmarsh station were intermediate between those of microalgae, Spartina anglica-litter and particulate organic matter. An in situ $\mathrm{H}^{13} \mathrm{CO}_{3}{ }^{-}$spike experiment at 2 tidal flat stations corroborated the importance of microphytobenthos as a carbon source for nematodes, yet at the same time contradicted the hypothesis that direct grazing would be the main pathway of microalgal carbon to nematode consumers. A laboratory experiment adding ${ }^{13} \mathrm{C}$-labeled algal detritus to sediment microcosms demonstrated the nematodes' ability to rapidly utilize settling organic matter too. Incorporation of carbon from phytodetritus by subsurface nematodes in both enrichment experiments was high, but, compared to carbon utilization by surface individuals, showed time-lags largely consistent with sediment mixing rates. A combination of observed natural isotope signatures and experimental results suggests that tidal flat nematodes preferentially utilize labile organic carbon derived from microphytobenthos or settling phytoplankton; organic matter from terrestrial or riverine origin does not contribute significantly to the diet of nematodes at our study sites.
\end{abstract}

KEY WORDS: Food web $\cdot$ Nematodes $\cdot$ Microphytobenthos $\cdot$ Phytoplankton $\cdot$ Intertidal estuarine ${ }^{13} \mathrm{C}$ Resale or republication not permitted without written consent of the publisher

\section{INTRODUCTION}

Several authors have suggested a potentially crucial role for the meiofauna in benthic energy fluxes (Gerlach 1971, Fenchel 1978, Coull \& Bell 1979, Kuipers et al. 1981), but detailed knowledge on their trophic position is lacking. Nematodes are consistently the most abundant meiobenthic taxon in estuarine sediments. In the meso- and polyhaline reaches of the Schelde estu-

*E-mail: tom.moens@rug.ac.be ary (SW Netherlands), they comprise on average more than $90 \%$ of the total metazoan meiofauna (Li \& Vincx 1993, Soetaert et al. 1994, Moens et al. 1999b).

Nematode communities are generally looked upon as grazers of microalgae and bacteria (Montagna 1995). Other feeding modes have, however, been proposed for many nematode taxa (Moens \& Vincx 1997 and references therein). Omnivores or facultative predators (sensu Moens \& Vincx 1997) are highly abundant in the meso- and polyhaline reaches of the Schelde estuary (Li \& Vincx 1993, Soetaert et al. 1994). These nematodes are known to aggregate on organic deposits (Lopez et 
al. 1979, Lorenzen et al. 1987, Prein 1988), where they probably utilize a mix of microbiota and particulate and dissolved organic matter (Moens et al. 1999c). Other nematodes, especially deposit-feeders, graze on microalgae but equally ingest other, similarly sized particles (Jensen 1987, Moens \& Vincx 1997).

In addition to microphytobenthic production (typically $\cong 100 \mathrm{~g} \mathrm{C} \mathrm{m}^{-2} \mathrm{yr}^{-1}$ on intertidal flats: De Jong \& de Jonge 1995, Heip et al. 1995, MacIntyre et al. 1996), organic matter of terrestrial, riverine, estuarine and marine origin may serve as carbon sources for estuarine food webs. Deegan \& Garritt (1997) demonstrated significant spatial variability in the estuarine food webs of the Plum Island Sound system, Massachusetts, USA. They concluded that (1) macrofaunal consumers primarily depend on autochthonous sources of organic matter, and (2) benthic and pelagic organisms largely utilize different organic sources, the former relying on benthic microalgae and saltmarsh vegetation, the latter on phytoplankton. Riera \& Richard (1996) also found a strong spatial variability in carbon sources used by the oyster Crassostrea gigas along an estuarine gradient in the Bay of Marennes-Oléron, France. Herman et al. (2000) used natural isotope ratios of carbon and nitrogen and isotope labeling approaches, and observed that intertidal macrobenthos relies primarily on microphytobenthos and suspended particulate organic matter, with little dependence on allochthonous carbon. No meiobenthos was, however, included in either of these studies.

We used stable isotopes to trace carbon sources for tidal flat nematodes in the lower part of the Schelde estuary. Natural stable isotope ratios are presented on a community level as well as for abundant species or genera belonging to different trophic types, and compared to isotope ratios of a range of organic sources in the Schelde estuary. An in situ $\mathrm{NaH}^{13} \mathrm{CO}_{3}$ enrichment experiment was performed to trace uptake of microphytobenthic carbon by tidal flat nematode communities. Finally, the nematodes' capacity to utilize freshly settled organic matter was assessed after addition of ${ }^{13} \mathrm{C}$-enriched algal detritus to sediment microcosms. Previous studies on meiobenthos from different marine and estuarine habitats and focusing on a variety of response times have yielded conflicting conclusions as to whether nematode communities utilize, and respond to, inputs of fresh algal detritus from the water column (see, e.g., Rudnick 1989, Gooday et al. 1996, Olafsson \& Elmgren 1997, Olafsson et al. 1999).

\section{MATERIALS AND METHODS}

Study sites. Samples were taken at 2 stations on the Molenplaat (MP 2 and MP 4), an intertidal flat at the meso-/polyhaline boundary in the turbid, nutrient-rich and heterotrophic Schelde estuary (average salinity between 20 and 25), and at 3 sites in and adjacent to the Paulina saltmarsh (average salinity between 24 and 32) (Fig. 1).

Most of the Molenplaat is located between $-1 \mathrm{~m}$ and $+1 \mathrm{~m}$ relative to mean tidal level. Mean tidal range is approximately $5 \mathrm{~m}$. The period of emersion is about $7 \mathrm{~h}$ per tidal cycle. The 2 MP stations are characterized by contrasting sediment characteristics (Table 1). Diatoms largely dominate the microphytobenthos at both stations (Lucas \& Holligan 1999), as is the case along most of the Schelde estuary (Sabbe \& Vyverman 1991). Samples were collected from both stations during emersion in June 1997 in a period of bright summer weather near the end of a spring microphytobenthos and phytoplankton bloom; further samples were taken at MP 4 in March 1999 during a period of cold and rainy weather.

At Paulina, samples were taken at 3 stations (see Table 1 for sediment characteristics): Stn A (PS A) was located at the edge of a drainage gully in a small saltmarsh, in the lower vegetation zone, dominated by Spartina anglica. Stn B (PS B) was located ca. $500 \mathrm{~m}$ upstream from the marsh on an intertidal flat. Stn C (PS C)

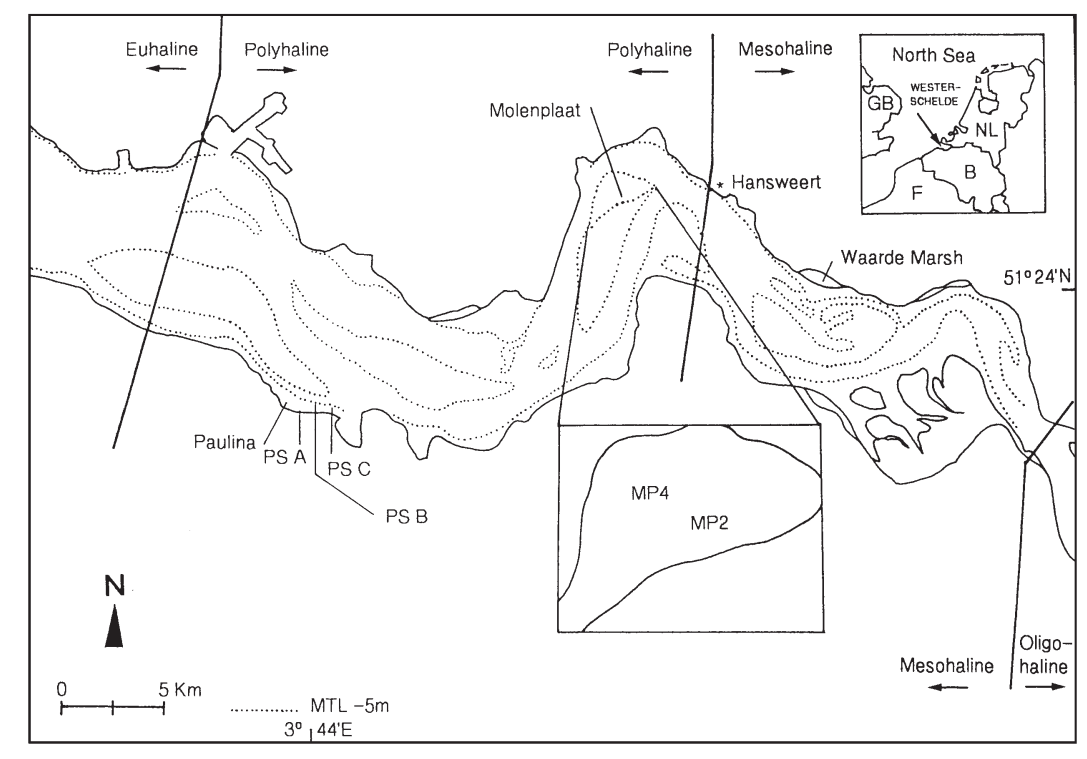

Fig. 1. Map of the Schelde estuary with indication of sampling stations chosen in the present study and those referred to in Table 4 
was located more than $1 \mathrm{~km}$ upstream of PS B on the same tidal flat, without direct influence of upstream saltmarsh vegetation. The Paulina sites were sampled in February 1998, during a period of relatively mild and sunny weather, with large diatom patches at PS A and B. Station B was also sampled in March 1999 when virtually no microphytobenthos patches were detectable.

Natural stable carbon isotope signatures of nematodes. First, we assessed small-scale horizontal heterogeneity of nematode carbon isotope ratios. Carbon isotope ratios of Enoploides longispiculosus from 10 cores at MP 4 were compared. In addition, we collected groups of 5 adults of the large facultative predator Adoncholaimus fuscus from each of 5 cores taken within a $1 \mathrm{~m}^{2}$ frame at PS A, as well as 5 individual adults taken from a single core. A. fuscus were separated live from freshly collected sediment after dispersion of sediment aliquots with artificial seawater (ASW: Dietrich \& Kalle 1957). All other nematode samples were stored frozen at $-20^{\circ} \mathrm{C}$ until treatment. Nematodes were collected from thawed samples via density centrifugation (Heip et al. 1985) with the colloidal silicagel Cecasol 40C (Sobrep) and subsequently rinsed with tap water. In a preliminary analysis, we checked whether sample treatment with $4 \%$ formaldehyde (as in the $\mathrm{H}^{13} \mathrm{CO}_{3}{ }^{-}$spike experiment) and colloidal silica affected nematode natural carbon isotope signatures. For this purpose, we compared isotope signatures of 5 groups of 3 A. fuscus which were handpicked live from untreated sediment with ratios of $A$. fuscus elutriated

Table 1. Summary of the most important characteristics of the Molenplaat (MP) and Paulina (PS) sampling stations. PS A is a saltmarsh station, all others are on bare tidal flats. MPB: microphytobenthos. Sediment grain size and organic carbon data for MP 2 and MP 4 are from 9 June 1996. nd: not determined

\begin{tabular}{|c|c|c|c|c|}
\hline $\begin{array}{l}\text { Stn } \\
\text { Depth } \\
\text { range }(\mathrm{cm})\end{array}$ & $\%$ mud & $\begin{array}{l}\text { Median } \\
\text { grain size } \\
\quad(\mu \mathrm{m})\end{array}$ & $\begin{array}{l}\text { Organic } \\
\text { carbon } \\
\text { (wt \%) }\end{array}$ & $\begin{array}{c}\text { MPB } \\
\text { production } \\
\left(\mathrm{mgC} \mathrm{m}^{-2} \mathrm{~h}^{-1}\right)\end{array}$ \\
\hline \multicolumn{5}{|l|}{ MP 2} \\
\hline $0-1$ & 43 & 77 & 0.64 & \multirow[t]{2}{*}{105} \\
\hline $0-25$ & 30 & 94 & 0.41 & \\
\hline \multicolumn{5}{|l|}{ MP 4} \\
\hline $0-1$ & 4 & 170 & 0.06 & \multirow[t]{2}{*}{131} \\
\hline $0-25$ & 5 & 167 & 0.07 & \\
\hline \multicolumn{5}{|l|}{ PS A } \\
\hline $0-1$ & 29 & 93 & 1.17 & \multirow[t]{2}{*}{ nd } \\
\hline $0-10$ & 25 & 98 & 1.44 & \\
\hline \multicolumn{5}{|l|}{ PS B } \\
\hline $0-1$ & 9 & 166 & 0.24 & \multirow[t]{2}{*}{ nd } \\
\hline $0-10$ & 6 & 171 & 0.18 & \\
\hline \multicolumn{5}{|l|}{ PS C } \\
\hline $0-1$ & 0 & 231 & 0.08 & \multirow[t]{2}{*}{ nd } \\
\hline $0-10$ & 0 & 229 & 0.07 & \\
\hline
\end{tabular}

with colloidal silica from (1) frozen and (2) formaldehyde-preserved samples. We also compared isotope signatures of 3 untreated PS B nematode (whole-community) samples with those of frozen or formaldehydepreserved samples elutriated with colloidal silica.

Nematodes were handpicked with a fine needle, rinsed twice in sterile ASW to remove adhering particles, and finally transferred to a drop of distilled water in $2.5 \times 6 \mathrm{~mm}$ aluminium cups (Van Loenen Instruments). Pretreatment of the aluminium cups for $4 \mathrm{~h}$ at $550^{\circ} \mathrm{C}$ ensured that they were not contaminated with exogenous organic carbon. Nematodes which did not appear clean after 2 transfers were discarded. The aluminium cups were oven-dried, pinched closed, and stored in screw-cap glass tubes until analysis. The number of nematodes sample ${ }^{-1}$ depended on crude biomass estimates based on observations of length and width of selected specimens. Carbon was conservatively estimated at $10 \%$ of nematode wet weight (Sikora et al. 1977, Heip et al. 1985). Except for some samples from the enrichment experiments, we always collected at least $10 \mu \mathrm{gC} \mathrm{sample}{ }^{-1}$, corresponding to 50 to 200 specimens in whole-community samples and to 20 or more Enoploides longispiculosus. Adult Adoncholaimus fuscus yielded $\geq 5 \mu \mathrm{gC}$ individual ${ }^{-1}$, sufficient for reproducible measurements.

The carbon isotopic composition of the samples was determined with a Fisons $\mathrm{CN}$-analyser coupled online via a con-flo 2 interface to a Finnigan Delta $\mathrm{S}$ mass spectrometer. Results are reported in the $\delta$ notation relative to Vienna PDB and expressed in units of \%, according to the standard formula:

$$
\delta^{13} \mathrm{C}=\left[\left(\mathrm{R}_{\text {sample }} / \mathrm{R}_{\text {standard }}\right)-1\right] \times 10^{3}
$$

Reproducibility of $\delta^{13} \mathrm{C}$ values was better than $0.2 \%$.

Differences between sampling sites and sampling times were compared by 1-way analysis of variance (ANOVA); unplanned pairwise comparisons were based on Hochberg's GT2-method for unequal sample sizes as recommended by Sokal \& Rohlf (1995), with Bonferroni correction for multiple pairwise tests. Data were normally distributed and homoscedastic, and hence not transformed prior to analysis.

Consumption of microalgal carbon by nematodes. In the field experiment, conducted at MP 2 and MP 4 in June 1997, we introduced $\mathrm{NaH}^{13} \mathrm{CO}_{3}$ in situ in a final concentration of $1 \mathrm{~g}^{13} \mathrm{C} \mathrm{m}^{-2}$, by spraying the sediment surface of two $0.25 \mathrm{~m}^{2}$ frames at the beginning of low tide. A detailed description of this experiment is given by Middelburg et al. (2000). The introduced ${ }^{13} \mathrm{C}$ was incorporated by the microphytobenthos, and its fate recorded over a period of $3 \mathrm{~d}$ (MP 4) or $4 \mathrm{~d}$ (MP 2). Duplicate $2.4 \mathrm{~cm}$ diam. cores for nematode $\mathrm{C}$-isotope analysis were taken after $1,2,4,24,48,72$ and $96 \mathrm{~h}$. The upper 3 centimetres were vertically subdivided 
per $\mathrm{cm}$ and preserved with hot $\left(70^{\circ} \mathrm{C}\right)$ neutral formaldehyde in a final concentration of approximately $4 \%$. Nematodes were extracted from these samples as already described.

In the laboratory experiment, we used two $14 \mathrm{~cm}$ diam. Perspex cores with sediment collected from PS B in March 1999. Ambient temperature at the time and site of sampling was approximately $10^{\circ} \mathrm{C}$. Cores were transported to the laboratory within $2 \mathrm{~h}$ of collection and incubated with $3 \mathrm{~cm}$ of overlying habitat water in a dark room at $14^{\circ} \mathrm{C}$. After an acclimatisation period of $24 \mathrm{~h}$, the overlying water was gently siphoned off, taking care to minimize sediment disturbance, and replaced by $154 \mathrm{ml}$ of ASW containing $77 \mathrm{mg}$ of ${ }^{13} \mathrm{C}$-enriched lyophilised algal material $\left(98 \%{ }^{13} \mathrm{C}\right.$ : Cambridge Isotope Laboratories). Thus, average sediment water cover was $1 \mathrm{~cm}$ and organic matter enrichment $0.5 \mathrm{mg} \mathrm{cm}^{-2}$ (i.e. approximately $1.5 \mathrm{~g} \mathrm{C} \mathrm{m}^{-2}$ ). Added algal carbon represented 1 to $2 \%$ of the total particulate organic carbon in the upper $1 \mathrm{~cm}$ interval of the sediment. The phytodetritus was allowed to settle for $1 \mathrm{~h}$, and this moment is referred to as Time zero for the experiment. $3.6 \mathrm{~cm}$ diam. perspex cores were inserted at time zero and single cores (1 from each $14 \mathrm{~cm}$ diam. core) were withdrawn after $0.5,3,24$ and $72 \mathrm{~h}$ for nematode carbon-isotope analysis. Small sediment fractions were oven-dried and used for the determina- tion of sedimentary organic carbon-isotope signatures after acidification with $\mathrm{HCl}$. Nematodes were elutriated and treated as in the previous experiment.

The amount of ${ }^{13} \mathrm{C}$ incorporated by nematodes in both enrichment experiments was calculated as the product of excess ${ }^{13} \mathrm{C}(E)$ and nematode biomass for each depth layer. Excess ${ }^{13} \mathrm{C}$ is the difference between the fraction ${ }^{13} \mathrm{C}(F)$ of control and sample, i.e.

$$
E=F_{\text {sample }}-F_{\text {control }}
$$

with $F={ }^{13} C /\left({ }^{13} C+{ }^{12} C\right)=R /(R+1)$, and $R=\left(\delta^{13} C / 1000+1\right)$ $\times R_{\mathrm{VPDB}}$, where $R_{\mathrm{VPDB}}=0.0112372=$ the carbon isotope ratio of the reference material (Vienna PDB).

\section{RESULTS}

\section{Natural stable carbon isotope signatures of nematodes}

Small-scale horizontal heterogeneity typically spanned a range of 2 to $3 \%$. It was smaller for samples containing higher nematode numbers, e.g. whole-community samples and most samples of specific genera. As an example, $\delta^{13} \mathrm{C}$ of 10 Enoploides longispiculosus samples from MP 4 in March 1999 averaged $-15.43 \pm 0.68 \%$ o (SD), with highest and lowest values of -14.09 and $-16.14 \%$, respectively. In a pool of 10 samples of the facultative predator Adoncholaimus fuscus (PS A, February 1998), $\delta^{13} \mathrm{C}$ ranged from -16.22 to $-19.20 \%$ with a mean of $-17.64 \%$. Nematodes collected live from sediments (1) did not show significantly different $\delta^{13} \mathrm{C}$ values compared to nematodes elutriated with Ludox from frozen (2) or formaldehyde-preserved (3) samples $(-18.5,-18.4$ and -16.5 , respectively, in A. fuscus, and $-14.7,-14.3$ and -13.4 in whole-community samples). The general tendency of formaldehydepreserved samples to be heavier does, however, warrant caution with the use of chemical preservatives when studying natural (i.e. non-enriched) carbonisotope ratios.

Nematodes collected at different sites and/or times had significantly different isotopic signatures $(\mathrm{p}=0.000$, $\left.\mathrm{df}_{\text {among }}=7, \mathrm{df}_{\text {within }}=48, F_{\mathrm{s}}=17.05\right)$. Nematodes from PS A, i.e. in the saltmarsh, were significantly more depleted in ${ }^{13} \mathrm{C}$ compared to Stns B and $C(p<0.01)$; the latter 2 did not differ (Table 2). In June 1997, nematodes at MP 2 were slightly but signifi- 
Table 3. Natural $\delta^{13} \mathrm{C}$ ratios (\%) of nematode genera collected from stations at Paulina. Stn A is a saltmarsh station, Stns B and $\mathrm{C}$ are unvegetated tidal flat stations. DF: deposit feeder (mainly herbivorous); CF: ciliate feeder; EF: epistrate feeder (mainly herbivorous); P: predator; FP: facultative predator

\begin{tabular}{|lrrr|}
\hline Nematode & \multicolumn{3}{c|}{ Stn } \\
& A & B & C \\
\hline Whole community & -17.39 & -14.42 & -14.12 \\
Whole community & -17.47 & -15.45 & -14.42 \\
Daptonema (DF) & & -13.90 & \\
Tripyloides (CF) & & -14.84 & \\
Sphaerolaimus (P) & -16.10 & -14.53 & \\
Enoplus (P or FP) & -19.09 & -14.52 & -13.39 \\
Adoncholaimus (FP) & -17.20 & -15.14 & -14.53 \\
Metachromadora (EF) & -15.07 & & \\
Calyptronema (P) & -15.97 & & \\
Axonolaimus (DF) & -17.95 & & \\
Praeacanthonchus (DF) & -17.02 & & \\
Halichoanolaimus (P) & -18.66 & & -14.83 \\
Unidentified & & & -14.18 \\
Oncholaimus (FP) & & & -12.73 \\
Enoploides (P) & & & \\
Average & -17.194 & -14.686 & -14.029 \\
SD & 1.169 & 0.509 & 0.727 \\
& & & \\
\hline
\end{tabular}

cantly ( $p<0.01)$ more depleted in ${ }^{13} \mathrm{C}$ than individuals at MP 4 , but had $\delta^{13} \mathrm{C}$ values overlapping with MP 4 nematodes collected in March 1999. The predacious Enoploides longispiculosus was isotopically heavier than other nematodes at MP 4 ( $\mathrm{p}<0.01$ in June 1997). $\delta^{13} \mathrm{C}$ of E. longispiculosus did not differ between June 1997 and March 1999, but $\delta^{13} \mathrm{C}$ of other nematodes did (being isotopically heavier in June: p < 0.01) (Table 2).

Table 3 presents $\delta^{13} \mathrm{C}$ signatures of different nematode genera and trophic types at the Paulina stations. Adequate replication was not possible due to lack of material; consequently no significance could be attributed to the observed trends. At Stn A, the epistratefeeding nematode Metachromadora and the predatory nematode genera Sphaerolaimus and Calyptronema were isotopically heavier than whole-community samples, dominated by deposit-feeding and facultatively predatory genera. This did not, however, hold for other supposedly predatory or facultatively predatory nematodes. No trends were found for PS B samples. At Stn C, predatory genera again appeared isotopically heavier than other nematodes.

Two genera, Adoncholaimus and Enoplus, were common to all 3 Paulina stations, and clearly showed the same trend as revealed by the comparison of all samples per station: specimens from the saltmarsh station PS A were more depleted in ${ }^{13} \mathrm{C}$ than specimens from the other stations. Sphaerolaimus was obtained from 2 of the 3 stations; here too, saltmarsh Sphaerolaimus were isotopically lighter than their congeners from PS B.

\section{Consumption of microalgal carbon by nematodes}

In the $\mathrm{H}^{13} \mathrm{CO}_{3}^{-}$enrichment experiment on the Molenplaat, nematodes at both stations rapidly incorporated microphytobenthic ${ }^{13} \mathrm{C}$ (Fig. 2). Uptake kinetics and excess ${ }^{13} \mathrm{C}$-levels were similar for both stations, except for the return to near natural values at MP 4 after $24 \mathrm{~h}$, for which we have no other explanation than horizontal heterogeneity in label administration to the sediment. Total carbon assimilated by the nematodes was roughly proportional to nematode biomass, but did not relate to trophic structure of the nematode community, which was largely dominated by the predacious Enoploides longispiculosus at MP 4, and by a mix of ciliate-feeders, deposit-feeders, epistrate-
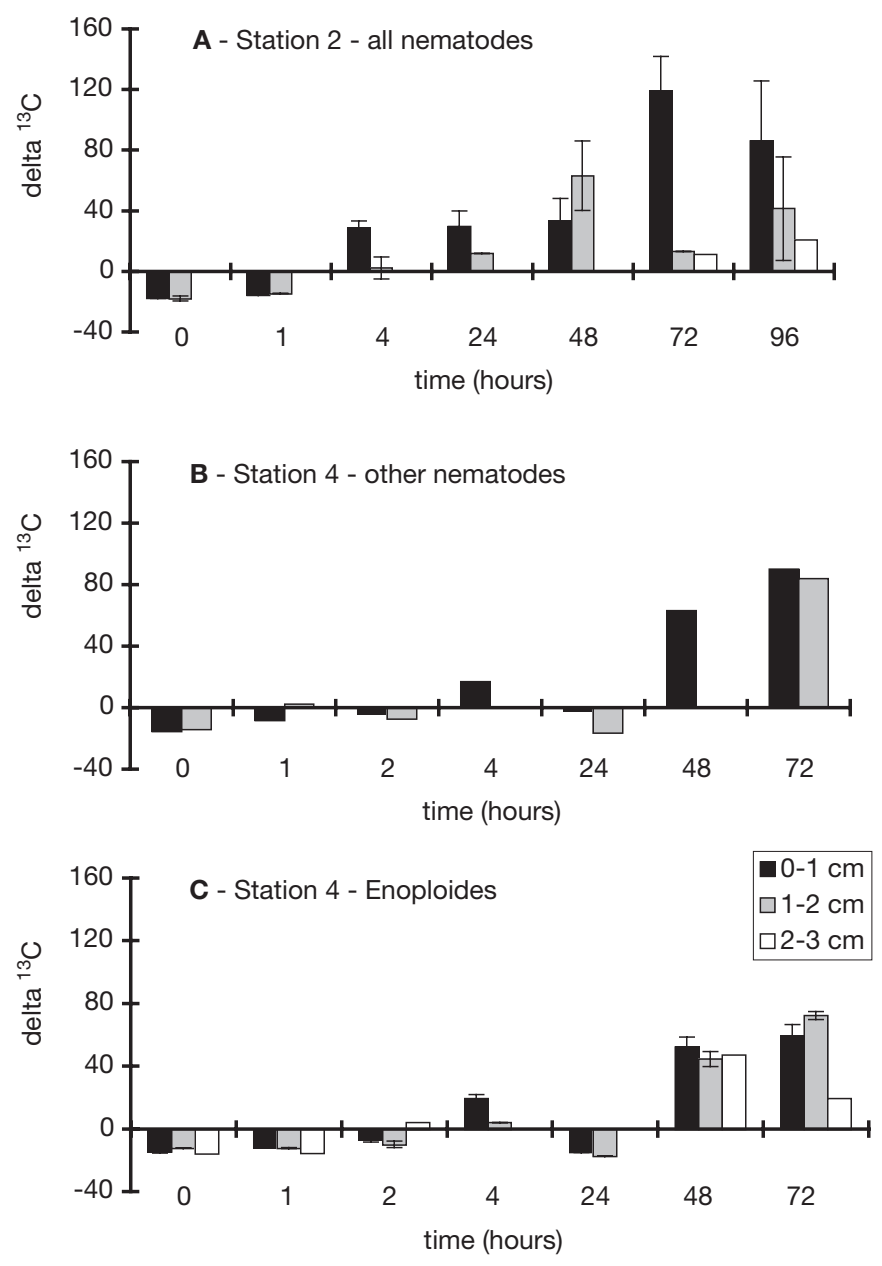

Fig. 2. $\mathrm{H}^{13} \mathrm{CO}_{3}{ }^{-}$pulse-chase experiment: stable carbon isotope ratios of the nematode fauna at MP 2 ( $\mathrm{A}$, all nematodes) and MP 4 (B, all nematodes except Enoploides longispiculosus; C, E. longispiculosus), as a function of time and sediment depth. Data are means $\pm \mathrm{SD}$ of 2 replicates. Data without error bars are measurements on pooled nematofauna of 2 replicate samples 

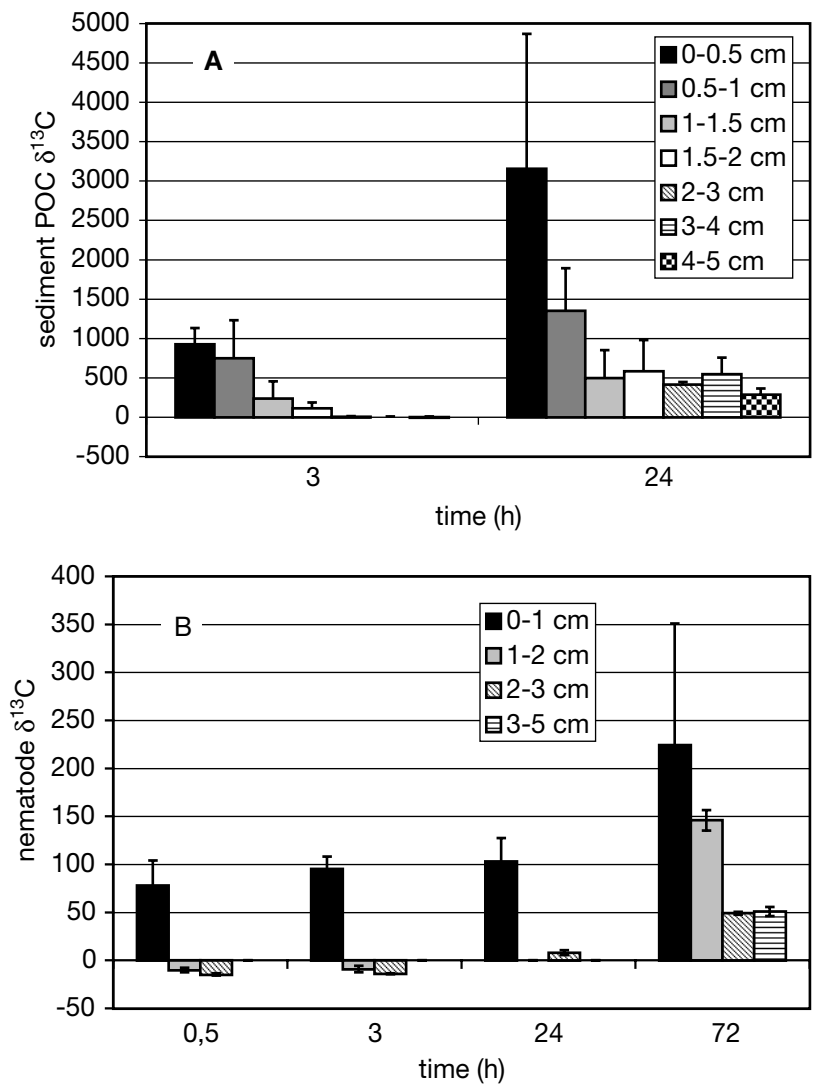

Fig. 3. Labeled algae experiment: stable carbon-isotope ratios of bulk sedimentary organic carbon (A) and of 'total nematodes' (B) as a function of time and depth. In (B), depth layers of $1-2,2-3$ and $3-5 \mathrm{~cm}$ have been pooled. Data are means $+\mathrm{SD}$ of 2 replicates

feeders and facultative predators at MP 2. At MP 4, nematodes from below $1 \mathrm{~cm}$ became more rapidly enriched in ${ }^{13} \mathrm{C}$ than at MP 2.

In the detritus sedimentation experiment, tidal effects were excluded. ${ }^{13} \mathrm{C}$ uptake by nematodes below $1 \mathrm{~cm}$ depth remained low until at least $24 \mathrm{~h}$; after $72 \mathrm{~h}$, enrichment in nematodes between 1 and $2 \mathrm{~cm}$ was comparable to ${ }^{13} \mathrm{C}$ enrichment in upper $1 \mathrm{~cm}$ nematodes after $24 \mathrm{~h}$, and twice as high as enrichment in nematodes below a depth of $2 \mathrm{~cm}$ (Fig. 3). Total particulate organic matter analyses on sediment showed that the algal detritus initially (up to $3 \mathrm{~h}$ ) remained on or near the sediment surface. After $24 \mathrm{~h}$, however, algal carbon had penetrated down to a depth of $5 \mathrm{~cm}$ (the deepest layer analyzed: Fig. 3A). This is reflected, albeit with a time-lag, in the $\delta^{13} \mathrm{C}$ depth profile of nematodes (Fig. 3B). Hence, nematodes in subsurface layers utilized sedimented algal detritus, but less rapidly than did surface nematodes.

The total amount of ${ }^{13} \mathrm{C}$ incorporated by nematodes was similar for both enrichment experiments $(0.54$ and $0.25 \mathrm{mg}^{13} \mathrm{C} \mathrm{m}^{-2}$ at MP 4 and 2, respectively, and
$2 \mathrm{mg}^{13} \mathrm{C} \mathrm{m}^{-2}$ at PS B), differences being attributable to differences in (1) nematode biomass between sites (averaging 0.67, 0.18 and $1.2 \mathrm{~g} \mathrm{C} \mathrm{m}^{-2}$ at MP 4, MP 2 and PS B, respectively) and $(2){ }^{13} \mathrm{C}$ enrichment of substrates.

\section{DISCUSSION}

This study used stable isotopes of carbon to infer food sources of estuarine tidal flat nematodes. Many authors have advocated a multiple stable-isotope approach to trace food sources for heterotrophic organisms, including nitrogen and sulphur isotopes (e.g. Peterson \& Fry 1987, Deegan \& Garritt 1997). However, the amount of biomass available for the taxonomic and vertical resolution aimed at in this study was not sufficient for additional $\mathrm{N}$ and $\mathrm{S}$ isotope analyses. Carbon isotope fractionation during heterotrophic processing is limited (DeNiro \& Epstein 1978, Rau et al. 1983); hence, the resolution power of the technique depends on the magnitude and consistency of isotopic differences of potential substrates. In the Schelde estuary, the isotope signatures of the main organic matter sources considered were sufficiently different, except for the discrimination between phytoplankton and other suspended particulate organic matter (Middelburg et al. 1997, Middelburg \& Nieuwenhuize 1998, Herman et al. 2000).

\section{Isotope ratios of potential food sources}

Table 4 summarizes the available information on carbon isotope ratios of the main organic matter sources in the Schelde estuary. Macroalgae and seagrasses are not considered here because they represent but a very small carbon input (macroalgae) or are absent (seagrasses) from the estuary. Microphytobenthos $\delta^{13} \mathrm{C}$ at our study sites is in the range typical of saltmarsh and tidal flat benthic microalgae (Currin et al. 1995, Riera et al. 1996, Deegan \& Garritt 1997). Unfortunately, the data on microphytobenthos and sedimentary POM at the Paulina sites were not obtained at the same time as the nematode samples. Available data on MP 4 and PS B indicate that seasonal variability in sedimentary POM carbon-isotope ratios is limited. While seasonal shifts in microalgal $\delta^{13} \mathrm{C}$ have been documented (e.g. Schwinghamer et al. 1983), they appear to be relatively small on a 'community basis' (Currin et al. 1995, Riera et al. 1996, Deegan \& Garritt 1997). Phytoplankton $\delta^{13} \mathrm{C}$ in this section of the estuary is not much different from bulk suspended POM (J.J.M. unpubl. data). $\delta^{13} \mathrm{C}$ of bulk sedimentary POM on the Molenplaat in June 1997 averaged -23\%o (Herman et al. 2000). 
Nematodes from PS A, in a saltmarsh gully, were collected near a Spartina anglica-dominated vegetation. The carbon-isotope signature of Spartina spp. is typically in the order of -12 to $-13 \%$ (Currin et al. 1995, Créach et al. 1997, Deegan \& Garritt 1997, Middelburg et al. 1997). Preferential decomposition of relatively heavy, labile components generally leads to only a small ${ }^{13} \mathrm{C}$ depletion (1 to $2 \%$ ) in Spartina spp. detritus relative to fresh tissue (Ember et al.
1987, Benner et al. 1991, Middelburg et al. 1997). However, bulk sediment organic matter in saltmarshes is generally ${ }^{13} \mathrm{C}$ depleted by 9 to $12 \%$ relative to fresh Spartina spp. tissue, probably as a result of input and retention of lighter allochthonous carbon (Middelburg et al. 1997). In the Waarde saltmarsh in the Schelde estuary, sedimentary $\delta^{13} \mathrm{C}$ was $-22 \%$ in the upper $5 \mathrm{~cm}$ (Middelburg et al. 1997), close to the value at PS A (-23\%).

Table 4. Stable carbon isotope signatures of organic carbon sources in the Schelde estuary (locations as in Fig. 1). Present study data are from single analyses (February 1998) or are means and standard deviations of 2 replicate cores (June 2000)

\begin{tabular}{|c|c|c|c|c|}
\hline Carbon source & Location & Date & $\delta^{13} \mathrm{C}$ & Source \\
\hline \multirow[t]{5}{*}{ Microphytobenthos } & MP 2 & Jun 1997 & $-16 \pm 2$ & Middelburg et al. (2000) \\
\hline & MP 4 & Jun 1997 & -14 to -15 & Herman et al. (2000) \\
\hline & PS A & Jun 2000 & $-17,42$ & Present study \\
\hline & PS B & Jun 2000 & $-18,19$ & Present study \\
\hline & PS C & Jun 2000 & $-21,09$ & Present study \\
\hline Bacteria (upper mm) & MP 2 & Jun 1997 & $-14.5 \pm 2$ & Middelburg et al. (2000) \\
\hline \multirow{23}{*}{ Bulk sediment POC } & MP 2: top $10 \mathrm{~cm}$ & Jun 1997 & -23 & Herman et al. (2000) \\
\hline & MP 2: top mm & Jun 1997 & $-22,3$ & Herman et al. (2000) \\
\hline & MP 4: top $10 \mathrm{~cm}$ & Jun 1997 & $-21,8$ & Herman et al. (2000) \\
\hline & MP 4: top mm & Jun 1997 & $-19,3$ & Herman et al. (2000) \\
\hline & MP 4: top $10 \mathrm{~cm}$ & Mar 1999 & $-21,8$ & J.J.M. (unpubl. data) \\
\hline & MP 4: top $\mathrm{cm}$ & Mar 1999 & $-22,7$ & J.J.M. (unpubl. data) \\
\hline & MP 4: top mm & Mar 1999 & $-23,8$ & J.J.M. (unpubl. data) \\
\hline & PS A: upper $\mathrm{cm}$ & Jun 2000 & $-22.54 \pm 0.61$ & Present study \\
\hline & PS A: $1-2 \mathrm{~cm}$ & Jun 2000 & $-23.23 \pm 0.06$ & Present study \\
\hline & PS A: $2-3 \mathrm{~cm}$ & Jun 2000 & $-22.95 \pm 0.12$ & Present study \\
\hline & PS A: $3-5 \mathrm{~cm}$ & Jun 2000 & $-23.41 \pm 0.23$ & Present study \\
\hline & PS B: upper $\mathrm{cm}$ & Jun 2000 & $-19.60 \pm 0.43$ & Present study \\
\hline & PS B: $1-2 \mathrm{~cm}$ & Jun 2000 & $-22.47 \pm 0.59$ & Present study \\
\hline & PS B: $2-3 \mathrm{~cm}$ & Jun 2000 & $-19.20 \pm 1.13$ & Present study \\
\hline & PS B: $3-5 \mathrm{~cm}$ & Jun 2000 & $-22.25 \pm 0.42$ & Present study \\
\hline & PS C: upper $\mathrm{cm}$ & Jun 2000 & $-20.50 \pm 0.85$ & Present study \\
\hline & PS C: $1-2 \mathrm{~cm}$ & Jun 2000 & $-21.52 \pm 0.48$ & Present study \\
\hline & PS C: $2-3 \mathrm{~cm}$ & Jun 2000 & $-18.32 \pm 1.32$ & Present study \\
\hline & PS C: $3-5 \mathrm{~cm}$ & Jun 2000 & $-21.78 \pm 0.20$ & Present study \\
\hline & PS B: upper cm & Feb 1998 & -20.52 & Present study \\
\hline & PS B: $1-2 \mathrm{~cm}$ & Feb 1998 & -21.28 & Present study \\
\hline & PS B: $2-3 \mathrm{~cm}$ & Feb 1998 & -22.20 & Present study \\
\hline & PS B: $3-5 \mathrm{~cm}$ & Feb 1998 & -22.78 & Present study \\
\hline Spartina & Waarde marsh & Aug 1994 & -12.2 to -13.1 & Middelburg et al. (1997) \\
\hline Sediment & Waarde marsh & Aug 1994 & $-23.3 \pm 0.8$ & Middelburg et al. (1997) \\
\hline Sediment & Waarde flat & Aug 1994 & $-25,5$ & Middelburg et al. (1997) \\
\hline Sediment & Waarde flat & Aug 1996 & $-24.8 \pm 0.9$ & Boschker et al. (1999) \\
\hline Sediment & Waarde marsh & Aug 1996 & $-22.2 \pm 1.1$ & Boschker et al. (1999) \\
\hline Bacteria & Waarde marsh & Annual & $-19.6 \pm 1.2$ & Boschker et al. (1999) \\
\hline Pelagic bacteria & Hansweert & Apr 1997 & $-14.3 \pm 1.7$ & H. T. S. Boschker (unpubl. data) \\
\hline Algae & Hansweert & Apr 1997 & $-19.1 \pm 1.4$ & J.J.M. (unpubl. data) \\
\hline POC (bulk SPM) & Hansweert & Apr 1997 & $-22.1 \pm 0.5$ & J.J.M. (unpubl. data) \\
\hline POC (bulk SPM) & Molenplaat & Jun 1996 & $-24,2$ & J.J.M. (unpubl. data) \\
\hline POC (bulk SPM) & Molenplaat & Jun 1998 & $-23.9 \pm 0.1$ & J.J.M. (unpubl. data) \\
\hline POC (bulk SPM) & Salinity $20-25^{a}$ & Aug 1994 & $-20.1 \pm 1.7$ & Middelburg \& Nieuwenhuize (1998) \\
\hline $\mathrm{POC}$ & Marine end-member & Feb 1999 & -22.6 & Hellings et al. (1999) \\
\hline POC & Marine end-member & Apr 1999 & -23.2 & Hellings et al. (1999) \\
\hline POC & $20-35 \mathrm{~km}$ range $^{\mathrm{b}}$ & Feb 1999 & $-24.9 \pm 0.5$ & Hellings et al. (1999) \\
\hline Terrestrial matter & End-member & Aug 1994 & -26 & Middelburg \& Nieuwenhuize (1998) \\
\hline
\end{tabular}




\section{Site differences}

Our results for the natural stable carbon-isotope ratios of whole nematode communities on the sandy tidal flats (MP 4, PS B and PS C) are in accordance with the hypothesis that the microphytobenthos (MPB) constitutes an important carbon source for tidal flat nematodes (Riera et al. 1996). Application of a simple 2-source mixing model with microphytobenthos and either sedimentary POM or bulk suspended POM (SPM) as potential carbon sources allows an estimate of the relative dependence of the nematode community on MPB. We used the isotope ratios for MPB and sediment POM (top $10 \mathrm{~cm}$ ) listed in Table 4 and a bulk SPM value of -24 (J.J.M. unpubl. data); nematode isotope signatures were obtained from Table 2, but with a $1 \%$ correction for fractionation with trophic level (DeNiro \& Epstein 1978). Such calculations indicate a 66 to $70.5 \%$ dependence of MP 2 (total) nematodes on MPB in June. The respective values for MP 4 in June and March are 80 to $82 \%$ and 34 to $48 \%$, respectively. The March values have to be interpreted with caution, because MPB and SPM signatures for this period are not available. Similar calculations for the 3 Paulina sites indicate even higher nematode dependence on MPB, but again should be treated with caution for the same reason as for MP 4 in March.

These results are surprising, because a clear dominance of herbivorous nematodes has been reported in but very few studies conducted in temperate tidal estuaries (Bouwman et al. 1984), and such dominance does not apply to the current study sites. This discrepancy suggests that microphytobenthos carbon is routed to nematodes via other pathways than mere grazing, in accordance with results from the enrichment experiments (see below). The microphytobenthos is usually an assemblage of species, with potentially slightly different $\delta^{13} \mathrm{C}$ signatures. Such differences may in turn be reflected in small within-site interspecific variation in $\delta^{13} \mathrm{C}$ among supposedly herbivorous nematode species (e.g. species of Metachromadora, Axonolaimus and Praeacanthonchus at PS A: Table 3). A high feeding selectivity has been suggested for estuarine nematodes grazing on bacteria and microphytobenthos (Moens et al. 1999a,b).

An increased relative importance of POM at Stn 2 compared to Stn 4 is in line with extant organic matter concentrations (1 order of magnitude higher at MP 2 than MP 4) (Herman et al. 2000, Middelburg et al. 2000), as well as with the trophic structure of the respective nematode assemblages. Facultative predators and deposit-feeders dominate at MP 2, and both are capable of ingesting several types of POM (Moens \& Vincx 1997, Moens et al. 1999c). These feeding guilds are relatively rare in the upper sediment layers at MP 4.
It is worth noting that microphytobenthos biomass at MP 2 in June 1997 was several times higher than at MP 4 (Middelburg et al. 2000), and it may seem odd that this would not be reflected in nematode isotope signatures. However, contrary to standing stock, primary productivity does not differ between the 2 stations (Hamels et al. 1998). This apparent contradiction relates to the depth of the photic zone $(2.6 \mathrm{vs} 1 \mathrm{~mm}$ at MP 4 and 2, respectively: Barranguet \& Kromkamp 2000). Our data thus suggest that production rather than standing stock governs benthic consumer biomass, in accordance with observations on depositfeeding macrofauna at the same sites (Herman et al. 2000).

Meiofauna isotope ratios in the North Inlet Estuary, USA, reflected Spartina anglica as well as microphytobenthos, but ratios of both organic sources overlapped, precluding unequivocal interpretation (Couch 1989). In our study, isotope ratios of nematodes from an $S$. anglica-dominated site (PS A) did not reflect $S$. anglica, suggesting they derive their carbon from allochthonous organic matter, microphytobenthos, or both. Twosource mixing models with MPB and either $S$. anglica or sedimentary POM as carbon sources yield a dependence of nematodes on MPB carbon of (more than) 100 and $86 \%$, respectively. Interestingly, bacteria from another Spartina anglica-dominated mineral marsh in the Schelde estuary had an average $\delta^{13} \mathrm{C}$ of -19.6 with a range of -21.8 to -17.6 (Boschker et al. 1999), similar to the nematode values at Stn PS A. These isotope signatures are consistent with observations of significant non-macrophyte inputs and of relatively small transfers of Spartina sp. organic matter to sediments and heterotrophic organisms in Schelde saltmarshes (Middelburg et al. 1997, Boschker et al. 1999). They are also in line with data showing but a limited contribution of Spartina sp. to the diet of several saltmarsh invertebrates (Riera et al. 1999). However, a combination of $S$. anglica and allochthonous carbon could also explain the saltmarsh nematode $\delta^{13} \mathrm{C}$ observed in the present study (nematodes then deriving ca. $46.5 \%$ of their carbon from $S$. anglica and 53.5\% from sediment POM).

\section{Consumption of microalgal carbon by nematodes}

Nematodes at MP 2 and MP 4, including the predacious Enoploides longispiculosus, rapidly incorporated microphytobenthic carbon, suggesting that the benthic microbial food web rapidly utilized the freshly produced microphytobenthic carbon. In view of the high relative abundance of E. longispiculosus at MP 4, it is unlikely that predation on other nematodes constituted the main pathway of ${ }^{13} \mathrm{C}$ to this predacious nematode. Predation on ciliates has recently been shown to be an 
important feeding strategy of E. longispiculosus at MP 4 (Hamels et al. 2001). Direct utilization of microphytobenthic exopolymer secretions (see below) is another possible food-web link. The trophic structure of nematode communities of MP 2 and MP 4 also indicates that direct grazing on microalgae was not the predominant route of ${ }^{13} \mathrm{C}$ to nematodes. The amount of carbon assimilated by nematodes at MP 2 remained more or less constant from 4 to $48 \mathrm{~h}$, but increased thereafter, suggesting that basically different carbon sources were being utilized. Over the first $48 \mathrm{~h}$ these may have consisted of microphytobenthos and its extracellular secretions via direct grazing and via predation on herbivores, while later on recycled carbon may have become a prominent source for the nematode community. Utilization of microbial exopolymer secretions by meiofauna has been documented, but its ecological significance remains poorly understood (Lopez et al. 1979, Decho 1990, Decho \& Moriarty 1990).

Montagna (1995) suggested that nematode grazing on microphytobenthos may have a significant impact on primary production. Some authors have even found grazing to (temporarily) exceed primary productivity (Blanchard 1991, Montagna \& Yoon 1991). The results of our $\mathrm{H}^{13} \mathrm{CO}_{3}{ }^{-}$spike experiment do not support this conclusion. Nematodes at MP 2 and MP 4 incorporated less than $1 \%$ of the total amount of ${ }^{13} \mathrm{C}$ fixed by microphytobenthos (150 and $250 \mathrm{mg}{ }^{13} \mathrm{C} \mathrm{m}^{-2}$ at Stns MP 2 and MP 4, respectively: Middelburg et al. 2000). The observed data, of course, represent assimilation rather than grazing, and do not account for label losses due to respiration and excretion/defecation. However, even taking into account all these factors, nematode carbon utilization probably never constituted more than a few percent of primary production.

Uptake of phytodetritus ${ }^{13} \mathrm{C}$ by nematodes in the second enrichment experiment was almost instantaneous, but leveled off after $3 \mathrm{~h}$ and remained constant up to $24 \mathrm{~h}$. After $72 \mathrm{~h}$, a sharp increase in nematode $\delta^{13} \mathrm{C}$ was found. It is plausible that the rapid initial carbon utilization mainly reflects ingestion of detritus, while labeling during longer incubations again may result from different pathways, involving intermediate trophic steps between algal detritus and nematodes. In an experiment with ${ }^{14} \mathrm{C}$-labelled diatoms, Olafsson et al. (1999) found carbon uptake by nematodes capable of grazing diatoms as well as by species incapable of direct grazing. These authors, however, analyzed carbon uptake after a much longer incubation (4 wk) than in our experiments. A combination of their species-level approach with a determination of short-term uptake kinetics will be indispensible to unravel the different pathways of algal/detrital carbon through the meiobenthos. In a similar experimental setup, Moodley et al. (2000) demonstrated rapid uptake of settled Chlorella sp. by the dominant foraminifer Ammonia sp. in estuarine tidal flats. They also observed resource partitioning among different foraminiferal genera within the upper $1 \mathrm{~cm}$.

In contrast to Rudnick's (1989) suggestion that different carbon sources are utilized by surface and subsurface living nematodes, our results demonstrate that algal carbon produced on or administered to the sediment surface is rapidly incorporated by surface as well as subsurface nematodes. The different habitats sampled (subtidal vs intertidal in our study) may be a reason for this discrepancy. However, Olafsson et al. (1999) also found that carbon utilization by subtidal nematodes was unrelated to their vertical distribution in the sediment. In the $\mathrm{H}^{13} \mathrm{CO}_{3}{ }^{-}$pulse-chase experiment at MP 4, label uptake by subsurface nematodes almost coincided with uptake by surface individuals, while at MP 2 incorporation by subsurface nematodes lagged behind that of surface individuals. This is (to some extent) consistent with sediment mixing rates at both sites (Middelburg et al. 2000). However, the observation that nematodes below $1 \mathrm{~cm}$ at MP 4 became ${ }^{13} \mathrm{C}$-enriched before label penetration was observable at that depth corroborates vertical migration of Enoploides longispiculosus and several other nematode species during ebb tide at MP 4 (Steyaert et al. 2001). Vertical transport of fresh detritus by depositfeeding macrofauna (see, e.g., Levin et al. 1997) may proceed at rates of $>1 \mathrm{~cm} \mathrm{~d}^{-1}$ (Graf 1989) and may further facilitate its utilization by subsurface nematodes. Thus, in continental slope sediments, some deeper-dwelling fauna more readily assimilated settled phytodetritus than did near-surface forms (Blair et al. 1996, Levin et al. 1999).

In conclusion, this paper demonstrates that labile organic carbon, as derived from microphytobenthos and settled phytoplankton, constitutes an important carbon source for tidal flat nematode communities in the lower part of the Schelde estuary, albeit the pathways whereby microalgal organic matter is utilized remain as yet unclear. We found no indications that organic matter from terrestrial or riverine origin (with $\delta^{13} \mathrm{C}$ of end-member particulates of -26 and $-30 \%$, respectively: Middelburg \& Nieuwenhuize 1998) contributes significantly to the benthic food webs of our study sites. Apparently, tidal flat nematodes preferentially utilize labile, locally produced organic matter. This holds for surface- as well as subsurface-dwelling nematodes, time-lags between deposition/production on the sediment surface and assimilation of organic matter by subsurface individuals probably being determined by sediment mixing rates.

Acknowledgements. This is a contribution to the ELOISE Programme (ELOISE No. 276/23) in the framework of ECOFLAT, carried out under contract ENV4-CT96-0216 (EU programme 
Environment and Climate). Additional financial support was obtained from the Flemish Fund for Scientific Research FWO via contract G.0104.99, and from the University of Gent via contract BOF 98-03, 12050398. The first author is a postdoctoral fellow with the FWO. Annick van Kenhove and Christine Van der heyden are gratefully acknowledged for their aid in field sampling and sample processing. The crew of the research vessel 'Luctor' are acknowledged for transport to and from the Molenplaat. Joop Nieuwenhuize took responsibility for the carbon isotope analyses. Frank Dehairs, Liesbeth Hellings, Roel Pel, Roel Merckx, Kristin Coorevits and Dirk Van Gansbeke all provided invaluable help during preliminary experiments and analyses. Maaike Steyaert provided nematode biomass information for the Molenplaat stations. The comments of 4 anonymous referees greatly improved earlier manuscript drafts. This is publication number 2922 from the Netherlands Institute of Ecology, Yerseke.

\section{LITERATURE CITED}

Barranguet C, Kromkamp J (2000) Estimating primary production rates from photosynthetic electron transport in estuarine microphytobenthos. Mar Ecol Prog Ser 204:39-52

Benner R, Fogel ML, Sprague EK (1991) Diagenesis of belowground biomass of Spartina alterniflora in salt-marsh sediments. Limnol Oceanogr 36:1358-1374

Blair NE, Levin LA, DeMaster DJ, Plaia G (1996) The shortterm fate of fresh algal carbon in continental slope sediments. Limnol Oceanogr 41:1208-1219

Blanchard GF (1991) Measurement of meiofauna grazing rates on microphytobenthos: is primary production a limiting factor? J Exp Mar Biol Ecol 147:37-46

Boschker HTS, De Brouwer JFC, Cappenberg TE (1999) The contribution of macrophyte derived organic matter to microbial biomass in salt marsh sediments: stable carbonisotope analysis of microbial biomarkers. Limnol Oceanogr 44:309-319

Bouwman LA, Romeyn K, Admiraal W (1984) On the ecology of meiofauna in an organically polluted estuarine mudflat. Estuar Coast Shelf Sci 19:633-653

Couch CA (1989) Carbon and nitrogen stable isotopes of meiobenthos and their food resources. Estuar Coast Shelf Sci 28:433-441

Coull BC, Bell SS (1979) Perspectives of marine meiofaunal ecology. In: Livingston RJ (ed) Ecological processes in coastal and marine systems. Plenum Press, New York, p 189-216

Créach V, Schricke MT, Bertru G, Mariotti A (1997) Stable isotopes and gut analyses to determine feeding relationships in saltmarsh macroconsumers. Estuar Coast Shelf Sci 44:599-611

Currin CA, Newell SY, Paerl HW (1995) The role of standing dead Spartina alterniflora and benthic microalgae in salt marsh food webs: considerations based on multiple stable isotope analysis. Mar Ecol Prog Ser 121:99-116

Decho AW (1990) Microbial exopolymer secretions in ocean environments: their role(s) in food webs and marine processes. Oceanogr Mar Biol Annu Rev 28:73-153

Decho AW, Moriarty DJ (1990) Bacterial exopolymer utilization by a harpacticoid copepod: a methodology and results. Limnol Oceanogr 35:1039-1049

Deegan LA, Garritt RH (1997) Evidence for spatial variability in estuarine food webs. Mar Ecol Prog Ser 147:31-47

De Jong DJ, de Jonge VN (1995) Dynamics and distribution of microphytobenthic chlorophyll-a in the Western Scheldt estuary (SW Netherlands). Hydrobiologia 311:21-30
DeNiro MJ, Epstein S (1978) Influence of diet on the distribution of carbon isotopes in animals. Geochim Cosmochim Acta 42:495-506

Dietrich G, Kalle K (1957) Allgemeine Meereskunde: Eine Einführung in die Ozeanographie. Gebrüder Borntraeger, Berlin

Ember LM, Williams DF, Morris JT (1987) Processes that influence carbon isotope variations in salt marsh sediments. Mar Ecol Prog Ser 36:33-42

Fenchel $T$ (1978) The ecology of micro- and meiobenthos. Annu Rev Ecol Syst 9:99-121

Gerlach SA (1971) On the importance of marine meiofauna for benthos communities. Oecologia 6:176-190

Gooday AJ, Pfannkuche O, Lambshead PJD (1996) An apparent lack of response by metazoan meiofauna to phytodetritus deposition in the bathyal north-eastern Atlantic. J Mar Biol Assoc UK 76:297-310

Graf G (1989) Benthic-pelagic coupling in a deep-sea benthic community. Nature 341:437-439

Hamels I, Sabbe K, Muylaert K, Barranguet C, Lucas C, Herman PMJ, Vyverman W (1998) Organisation of microbenthic communities in intertidal estuarine flats, a case study from the Molenplaat (Westerschelde Estuary, The Netherlands). Eur J Protistol 34:308-320

Hamels I, Moens T, Muylaert K, Vyverman W (2001) Trophic interactions between ciliates and nematodes from an intertidal flat. Aquat Microb Ecol 26:61-72

Heip C, Vincx M, Vranken G (1985) The ecology of marine nematodes. Oceanogr Mar Biol Annu Rev 23:399-489

Heip CHR, Goosen NK, Herman PMJ, Kromkamp J, Middelburg JJ, Soetaert K (1995) Production and consumption of biological particles in temperate tidal estuaries. Oceanogr Mar Biol Annu Rev 33:1-149

Hellings L, Dehairs F, Tackx M, Keppens E, Baeyens W (1999) Origin and fate of organic carbon in the freshwater part of the Scheldt Estuary as traced by stable carbon isotope composition. Biogeochemistry 47:167-186

Herman PMJ, Middelburg JJ, Widdows J, Lucas CH, Heip CHR (2000) Stable isotopes as trophic tracers: combining field sampling and manipulative labelling of food resources for macrobenthos. Mar Ecol Prog Ser 204:79-92

Jensen P (1987) Feeding ecology of free-living aquatic nematodes. Mar Ecol Prog Ser 35:187-196

Kuipers BR, de Wilde PAWJ, Creutzberg F (1981) Energy flow in a tidal flat ecosystem. Mar Ecol Prog Ser 5:215-221

Levin LA, Blair NE, DeMaster DJ, Plaia G, Fornes W, Martin C, Thomas C (1997) Rapid subduction of organic matter by maldanid polychaetes on the North Carolina Slope. J Mar Res 55:595-611

Levin LA, Blair NE, Martin CM, DeMaster DJ, Plaia G, Thomas CJ (1999) Macrofaunal processing of phytodetritus at two sites on the Carolina margin: in situ experiments using ${ }^{13} \mathrm{C}$-labeled diatoms. Mar Ecol Prog Ser 182:37-54

Li Jian, Vincx M (1993) The temporal variation of intertidal nematodes in the Westerschelde. I. The importance of an estuarine gradient. Neth J Aquat Ecol 27:319-326

Lopez G, Riemann F, Schrage M (1979) Feeding biology of the brackish water oncholaimid nematode Adoncholaimus thalassophygas. Mar Biol 54:311-318

Lorenzen S, Prein M, Valentin C (1987) Mass aggregations of the free-living marine nematode Pontonema vulgare (Oncholaimidae) in organically polluted fjords. Mar Ecol Prog Ser 37:27-34

Lucas CH, Holligan PM (1999) Nature and ecological implications of algal pigment diversity on the Molenplaat tidal flat (Westerschelde estuary). Mar Ecol Prog Ser 180:51-64 MacIntyre HL, Geider RJ, Miller DC (1996) Microphytoben- 
thos: the ecological role of the 'secret garden' of unvegetated, shallow-water marine habitats. I. Distribution. Estuaries 19:186-201

Middelburg JJ, Nieuwenhuize J (1998) Carbon and nitrogen stable isotopes in suspended matter and sediments from the Schelde Estuary. Mar Chem 60:217-225

Middelburg JJ, Nieuwenhuize J, Lubberts RK, van de Plassche O (1997) Organic carbon isotope systematics of coastal marshes. Estuar Coast Shelf Sci 45:681-687

Middelburg JJ, Barranguet C, Boschker HTS, Herman PMJ, Moens T, Heip CHR (2000) The fate of intertidal microphytobenthos carbon. An in situ ${ }^{13} \mathrm{C}$ labelling study. Limnol Oceanogr 45:1224-1234

Moens T, Vincx M (1997) Observations on the feeding ecology of estuarine nematodes. J Mar Biol Assoc UK 77: 211-227

Moens T, Verbeeck L, De Maeyer A, Swings J, Vincx M (1999a) Selective attraction of marine bacterivorous nematodes to their bacterial food. Mar Ecol Prog Ser 176: $165-178$

Moens T, Van Gansbeke D, Vincx M (1999b) Linking estuarine intertidal nematodes to their suspected food: a case study from the Westerschelde Estuary (south-west Netherlands). J Mar Biol Assoc UK 79:1017-1027

Moens T, Verbeeck L, Vincx M (1999c) Feeding behaviour of a predatory and a facultatively predatory marine nematode (Enoploides longispiculosus and Adoncholaimus fuscus). Mar Biol 134:585-593

Montagna PA (1995) Rates of metazoan meiofaunal microbivory: a review. Vie Milieu 45:1-9

Montagna PA, Yoon WB (1991) The effect of freshwater inflow on meiofaunal consumption of sediment bacteria and microphytobenthos in San Antonio Bay, Texas, USA. Estuar Coast Shelf Sci 33:529-547

Moodley L, Boschker HTS, Middelburg JJ, Pel R, Herman PMJ, de Deckere E, Heip CHR (2000) Ecological significance of benthic foraminifera: ${ }^{13} \mathrm{C}$ labelling experiments. Mar Ecol Prog Ser 202:289-295

Olafsson E, Elmgren R (1997) Seasonal dynamics of sublittoral meiobenthos in relation to phytoplankton sedimentation in the Baltic Sea. Estuar Coast Shelf Sci 45:149-164

Olafsson E, Modig H, van de Bund WJ (1999) Species specific uptake of radio-labelled phytodetritus by benthic meiofauna from the Baltic Sea. Mar Ecol Prog Ser 177: $63-72$

Editorial responsibility: Otto Kinne (Editor), Oldendorf/Luhe, Germany
Peterson BJ, Fry B (1987) Stable isotopes in ecosystem studies. Annu Rev Ecol Syst 18:293-320

Prein M (1988) Evidence for a scavenging lifestyle in the freeliving nematode Pontonema vulgare (Enoplida, Oncholaimidae). Kiel Meeresforsch 6:389-394

Rau GH, Mearns AJ, Young DR, Olson RJ, Schafer HA, Kaplan IR (1983) Animal ${ }^{13} \mathrm{C} /{ }^{12} \mathrm{C}$ correlates with trophic level in pelagic food webs. Ecology 64:1314-1318

Riera P, Richard P (1996) Isotopic determination of food sources of Crassostrea gigas along a trophic gradient in the estuarine Bay of Marennes-Oléron. Estuar Coast Shelf Sci 42:347-360

Riera P, Richard P, Grémare A, Blanchard G (1996) Food source of intertidal nematodes in the Bay of MarennesOléron (France), as determined by dual stable isotope analysis. Mar Ecol Prog Ser 142:303-309

Riera P, Stal LJ, Nieuwenhuize J, Richard P, Blanchard G, Gentil F (1999) Determination of food sources for benthic invertebrates in a salt marsh (Aiguillon Bay, France) by carbon and nitrogen stable isotopes: importance of locally produced sources. Mar Ecol Prog Ser 187:301-307

Rudnick DT (1989) Time lags between the deposition and meiobenthic assimilation of phytodetritus. Mar Ecol Prog Ser 50:231-240

Sabbe K, Vyverman W (1991) Distribution of benthic diatom assemblages in the Westerschelde estuary (Zeeland, The Netherlands). Belg J Bot 124:91-101

Schwinghamer P, Tan FC, Gordon DC Jr (1983) Stable carbon isotope studies on the Pecks Cove mudflat ecosystem in the Cumberland Basin, Bay of Fundy. Can J Fish Aquat Sci 40(Suppl 1):262-272

Sikora JP, Sikora WB, Erkenbrecher CW, Coull BC (1977) Significance of ATP, carbon and caloric content of meiobentic nematodes in partitioning benthic biomass. Mar Biol 44: $7-14$

Soetaert K, Vincx M, Wittoeck J, Tulkens M, van Gansbeke D (1994) Spatial patterns of Westerschelde meiobenthos. Estuar Coast Shelf Sci 39:367-388

Sokal RR, Rohlf FJ (1995) Biometry: the principles and practice of statistics in biology research, 3rd edn. WH Freeman \& Co., New York

Steyaert M, Herman PMJ, Moens T, Widdows J, Vincx M (2001) Tidal migration of nematodes on an estuarine tidal flat (the Molenplaat, Schelde Estuary, SW Netherlands). Mar Ecol Prog Ser 224:299-304

Submitted: March 22, 2000; Accepted: January 24, 2002

Proofs received from author(s): April 26, 2002 